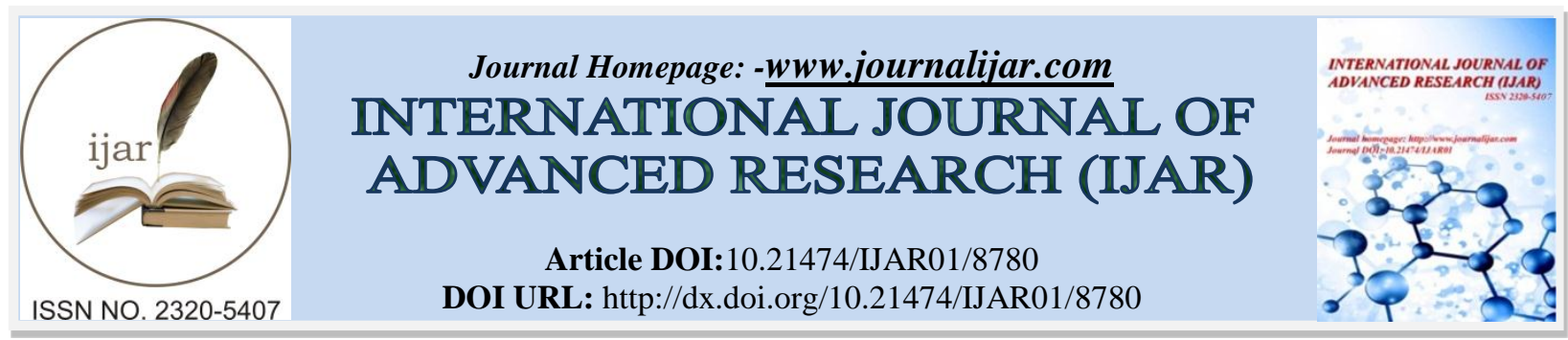

RESEARCH ARTICLE

\title{
THE ASSOCIATION AND DIFFERENCES OF OVERUSE INJURY OCCURRENCES AND TRAINING RELATED SUPPORTIVE FACTORS IN ETHIOPIAN YOUTH RUNNING ATHLETES.
}

1. (Ph.D) Ethiopian Youth Sports Academy.

\section{Amensisa Kebede Legesse ${ }^{1}$ and Teshom Kebede ${ }^{2}$.}

2. MSc. Ethiopian Youth Sports Academy.

\section{Manuscript Info}

Manuscript History

Received: 20 January 2019

Final Accepted: 22 February 2019

Published: March 2019

Key words:-

Overuse injury, long and short distance running, gender, risk factor, Training.

\section{Abstract}

Runners sustain injuries at an alarming rate. According to various epidemiologic studies (Rochcongar P, Pernes J, Carre F, et al. 1995; Walter SD, Hart LE, McIntosh JM, et al, 1989), between $27 \%$ and $70 \%$ of recreational and competitive distance runners can expect to be injured during any 1-year period. Overuse Injury was defined as an injury that causes pain during exercise loading without any noticeable external cause of injury (Beck 1998). Accordingly Different runningloading characteristics, overuse injury profiles and gender differences in injuries were investigated. In addition, training related risk factors for overuse injuries in Short, middle and long distance athletes were studied. This twelve-month retrospective questionnaire study comprised Ethiopian athletics training centres' ( Tirunesh Dibaba, Maychew, Bekoji, Hagerselam, Debrebirhan and Ethiopian Sport Academy) running athletes Short distance $(n=65)$, Middle distance $(n=75)$, and Long distance $(n=64)$ aged 16-21.

There was a difference in training related and supportive factors between overuse injured and uninjured athletes (Age, training age, BMI, annual Training exposure hours, weekly training hours and frequency, annual mileage, Rest and recovery days per week and Worming up length and frequency). However no association of gender and occurrence of overuse injury were found as a whole and split events of athletes (short, middle and long). Thus there are training related and supportive factors differences between athletes overuse injured and uninjured.

Copy Right, IJAR, 2019,. All rights reserved.

\section{Introduction:-}

For many athletes, sport is not safe enough without prevention, treatment, and medication of injury. There is also significant medical and economic cost associated with sports injury affecting athletes, teams and society. While Sport has been promoted, it also needs to be recognized that, as with any sport, running related injuries can and do occur. Sport participation in some cases can also lead to permanent disability (Bahr \& Holme, 2003). It is still an ongoing debate among sport medicine professionals and coaches whether athletic injuries are an inevitable part of athletics, or whether they may be predicted or even prevented by utilization of advanced coaching strategies and technologically safe equipment. To fully elaborate on the issues of different types of injuries among elite athletes, it 
is necessary to consider multiple factors, both the external and internal causes and consequences of injury (Slobounov, 2008).

Sport injuries are diverse, ranging from overuse injuries, acute injuries and metabolic abnormalities to extrinsic hazards such as dog bites and traffic collisions. In many cases athletics cannot be directly responsible for fatal injuries such as heat stroke, heart related just to name few among many. Internationally, there is considerable epidemiological literature on the incidence of running injuries. Numerous sports-related injuries occur each year, resulting in disability and time lost from training in addition to substantial medical costs (McMaster, Troup, 1998; Murphy DF, Connolly, Beynnon, 2003).

In relation to this several studies have investigated the risk factors for sports injuries in long-distance running (Hreljac, 2004; vanMechelen, 1992; Taunton, Ryan, Clement, McKenzie, Lloyd-Smith, \& Zumbo, 2003; Wen 2007), with special reference to lower extremity injuries (Hreljac, Marshall, \& Hume, 2000; Macera ,1992; Ristolainen 2012; Rolf 1995, Wen 2007). Those factors include age, anthropometrics, anatomical factors, training years, injury history, menstrual status, physical fitness, and psychological factors (Bahr, \& Holme 2003; Taimela, Kujala, \& Österman, 1990; van Mechelen, Hlobil, \& Kemper, 1992; Murphy, Connolly, \&Beynnon, 2003). The amount of exposure, sudden increased training or running distance (Collado, Sainani, \& Fredericson, 2011; Taunton et al, 2002; Tenforde, Sayres, McCurdy, Walter, \& Hart, 1990) or running volume (Lysholm, \& Wiklander, 1987): Training errors without enough resting and recovery time and fatigue as well as equipment, such as shoes, skies and poles can also be risk factors for an injury. Further, training surface has been found to be associated with injury risk (Wen ,2007). A hard training surface increases the risk for stress fractures (Knobloch , \& Yoon Vogt ,2008).

Similarly the current conceptualization of science of training, basic principles theories as well as specific safe methods of strength and conditioning for athletes training are common problems in most coaches and athletes that predispose them for an overtraining and injury. This can also have a significant negative impact on performance, health and daily life. Fortunately overtraining can be prevented by implementing a sensible training monitoring program and careful training planning. The easy-to-implement strategies and guidelines have been suggested by many recent research and real-life coaching and athletic experiences (Slobounov, 2008).

However, there is always a trade-off between high-achievement and probability of overtraining as well as high risk of injury among elite athletes. Proper planning, specificity and individualization of the training program are key factors to consider. There are tendencies in modern sports to (a) standardize the training program within certain sports; and (b) modify the exercise content to achieve maximal adaptation and reduce the probability of accommodation.

Consequently, it appears that Ethiopia lacks systemic injury and overtraining prevention research that has been translated into coaching practices. A systematic study of sports injuries and knowledge of risk factors and specific patterns of injury and overtraining treatments shall be studied. Generally, the aim of this research was to describe potential risk factors that are effective enough to predict injuries in running through translating injury prevention strategies in to coaching practices. Thus the study explained the occurrence and consequences of athletic overuse injuries with different athletics training loadings, risk factors and related scientific training patterns. The target group of this study comprised six Ethiopian national athletics centers Short, Middle and Long Distance Athletes.

\section{Statement of the Problem}

As sports participation increases, so does the incidence of both acute and over use sports-related injuries ; Moreover, the incidence further rises as the sport takes more time. In order to promote prevention of sportsrelated injuries, the magnitude and type of the problem must first be identified and described. In relation to this, systematic surveillance of sports injuries and knowledge of the risk factors and the specific patterns of injury treatment are inadequate in Ethiopia. With this end, Systemic study of the training science and Athletics injuries should be expanded in order to develop appropriate prevention programs. There is still a controversy among coaches regarding to the training programs and procedures. This is relevant to have a maximum performance without jeopardizing the athletes' health. Such problems definitely require scientific observations and evaluations. Despite the many sport injury classifications, injury profiles between gender and risk factor for overuse injury study is relevant. With this end the following research questions were formulated.

1. How was the current state of the Ethiopian junior running athletes overuse sport injuries at different events?

2. Was there any significant difference between the occurrences of overuse Injury? 


\section{Objectives of the Study}

The general purpose of the study was to investigate and describe and investigate the causes, consequences of training related risk factors for overuse injuries in running athletes

\section{Methodology:-}

Design of the Study

A triangulation mixed method design is used as a major way of conducting the research. In this type of design qualitative and quantitative data were used for supporting and validating each other.

\section{Participants of the Study}

Participants of the study were short, middle and long distance athletes of Ethiopian athletics training centers. The training centers are namely Tirunesh Dibaba ,Maychew, Debrebrehan, Bekoji , Hagerselam and Ethiopian youth sport academy of $2013 / 14$ athletes and coaches.

\section{Samples and Sampling Procedures of the Study}

All short, middle and long distance athletes were selected purposefully because of the assumption that they could provide relevant information due to their experience in the team and their small number. In general, Census or 204 of total athletes were included from the five athletics training centers for the main study.

\section{Data Collection Instruments}

Questionnaire was used as a major instrument to collect dataIn order to elicit the necessary data, a questionnaire was adopted for athletes from (Ristolainen 2012). However some items related to training were included to address the objectives of the study and gather more information. The questionnaire was validated by comparing questionnaire and interview responses after a one-week interval among 34 subjects from Ethiopian Light and Power Agency Sport Club. And the reliability of the background information questions was excellent: the intra class correlation coefficient (ICC) varied from 0.92 to 0.96 ( $\mathrm{p}<0.001)$. The reliability of sports and training information was good or excellent (ICC $=0.88$ to $0.94, \mathrm{p}<0.001$ ). The reliability of questions concerning acute and overuse sports injuries during twelve months varied from moderate to good $(\mathrm{ICC}=0.77$ to $0.89, \mathrm{p}<0.001)$.

\section{Method of Data Analysis:-}

Different methods of data analysis pertinent to the variables were employed. Therefore, the questionnaires were first collected, organized, tabulated and coded in SPSS version 20.. The following statistical procedures were employed for numerical interpretation.

1. Descriptive statistics like mean, grand mean and percentage were used to analyze basic information and distribution of scores. The frequency, percentage and mean values were also used to discuss the proportion for respondents along the item.

2. The ANOVA and t-test were employed to check whether there is significant difference or not between groups. Pearson chi-square statistics and analysis of variance were applied to calculate statistical association or differences in distributions between the different athletics sports.

\section{Analysis and Discussion:-}

\subsection{Occurrences of at least one overuse Injury}

Eighty seven athletes $(42.65, \mathrm{n}=87)$ reported at least one overuse injury. $41 \%$ of total female athletes face at least one overuse injury where as $43.8 \%$ of male athletes had at least one acute injury. A chi square test for independent (with rates continuity correction) indicated no significant association between gender and the occurrence of injury for all events $\mathrm{x}^{2}(1, \mathrm{n}=204)=.07, \mathrm{p}=.78, \mathrm{phi}=-.028$

A Chi-square split event test for independence (with rates continuity correction) indicated no significance association as well for male short distance athletes with $52.9 \%(18)$ and female short distance 35.5 (11) of at least one overuse injury occurrence of $\mathrm{x}^{2}(1, \mathrm{n}=65)=1.36, \mathrm{p}=.24$, $\mathrm{phi}=.18$

Male athletes have been reported to be at increased overall injury risk compared to female athletes (Kujala et al. 1995b, Junge et al. 2004b, Knowles et al. 2006a, Darrow et al. 2009, Hägglund et al. 2009). In contrast, Elias (2001) showed greater aggregate injury in female than male soccer players. Increased injury risk in female swimmers (Sallis et al. 2001) and high-school cross-country runners (Rauh et al. 2000, Tenforde et al. 2011) compared to 
males has been reported. Overall, in accordance with our findings, earlier studies have found no gender differences in overall injury incidence in different sports after adjustment for exposure time (Lanese et al. 1990, Messina et al. 1999, Wolf et al.2009).

Graph. 1:-Occurrence of at least one Injury

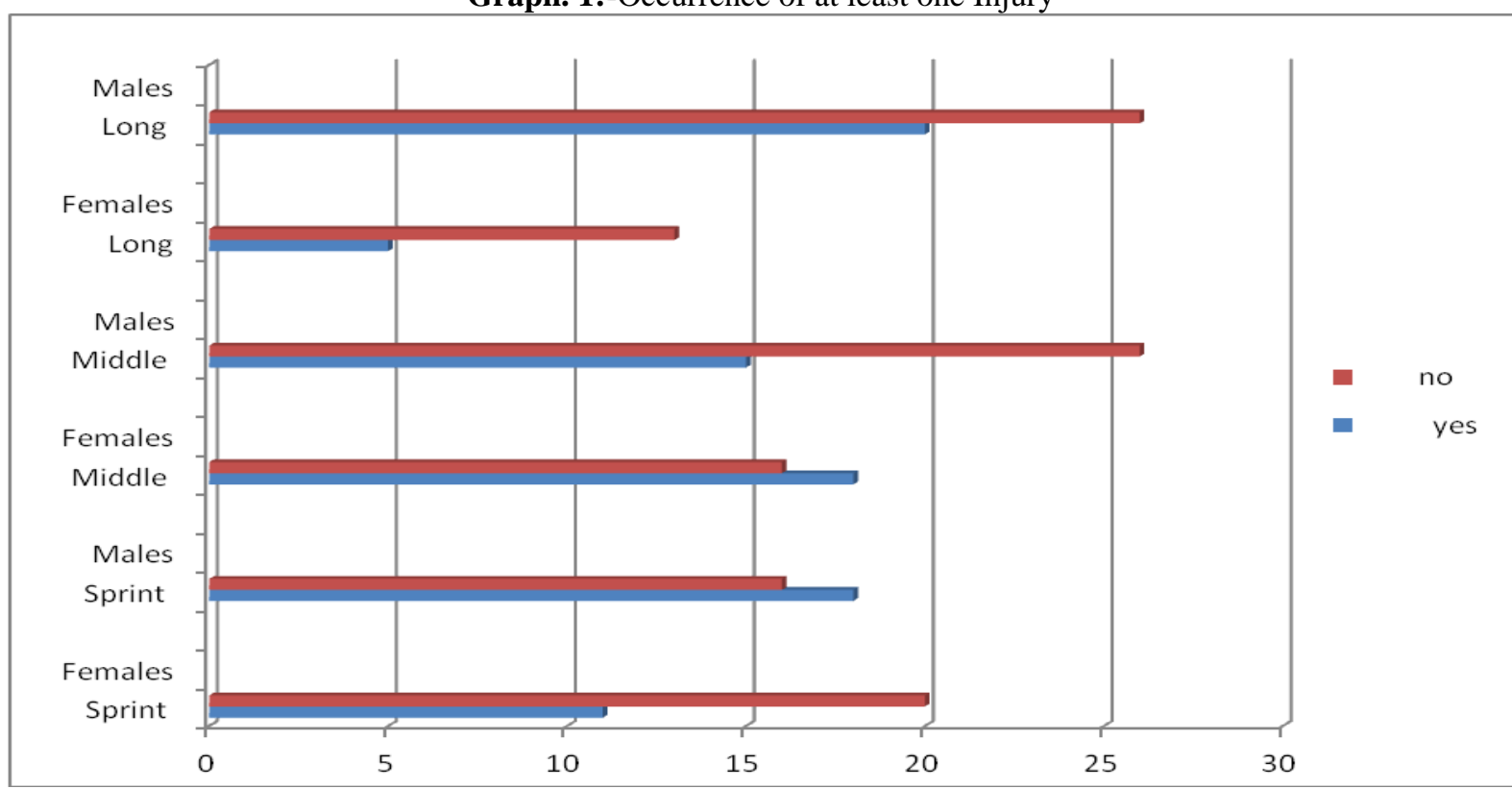

Similarly no significance difference is shown for middle distance athletes injury occurrence of males $63.4 \%$ ( 15) and females $52.9 \%(18) \mathrm{x}^{2}(1, \mathrm{n}=75)=1.41, \mathrm{p}=.24$, phi $=-.16$. A similar non significant difference is also shown for long distance athletes overuse injury occurrence across gender of females $27.8 \%(5)$ and males $43.5 \% \quad(n=20) x^{2}(1$, $\mathrm{n}=64)=.76, . \mathrm{p}=.38$, phi $=.1$

\subsection{Differences between Injured and Uninjured Athletes}

An independent - samples t-test was conducted to compare the training age mean scores for Overuse injured and uninjured. Results of the two-independent samples t-test for female long distance athletes overuse injury injured and uninjured athletes shows that the mean training age in the year differs between injured $(\mathrm{M}=2.34 \mathrm{SD}=1.13, \mathrm{n}=34)$ and uninjured $(\mathrm{M}=3.31, \mathrm{SD}=1.21, \mathrm{n}=49)$ at the .00 level of significance $(\underline{\mathrm{t}}=-3.68, \underline{\mathrm{df}}=81, \underline{\mathrm{p}}<.01,95 \% \mathrm{CI}$ for mean difference -1.49 to -.44 ).

Table 1:-Results of t-tests and Descriptive Statistics all Overuse Injured and Uninjured Female Athletes

\begin{tabular}{|c|c|c|c|c|c|c|c|c|c|}
\hline \multirow[t]{3}{*}{ Outcome } & \multicolumn{6}{|c|}{ Injury occurrence } & \multirow{3}{*}{$\begin{array}{l}\text { 95\% CI for } \\
\text { Mean } \\
\text { Difference }\end{array}$} & & \\
\hline & \multicolumn{3}{|c|}{ Injured/YES } & \multicolumn{3}{|c|}{ Uninjured/No } & & & \\
\hline & $\mathrm{M}$ & SD & $\mathrm{n}$ & $\mathrm{M}$ & SD & $\mathrm{n}$ & & $\mathrm{T}$ & $\mathrm{Df}$ \\
\hline Age & 17.3235 & 1.12062 & 34 & 17.0816 & 1.23890 & 49 & $\begin{array}{r}-.28753, \\
.77133\end{array}$ & .909 & 81 \\
\hline Height & 1.6318 & .06631 & 34 & 1.6100 & .05898 & 49 & $\begin{array}{r}-.00580, \\
.04933\end{array}$ & 1.571 & 81 \\
\hline BmI & 19.0526 & 2.06595 & 34 & 18.7053 & 1.64718 & 49 & $\begin{array}{c}-.46510 \\
1.15979\end{array}$ & .851 & 81 \\
\hline Weight & 50.6647 & 5.57521 & 34 & 48.4898 & 5.24453 & 49 & $\begin{array}{l}-21513, \\
4.56495\end{array}$ & 1.811 & 81 \\
\hline Training age & 2.3382 & 1.13298 & 34 & 3.3061 & 1.21113 & 49 & $\begin{array}{r}-1.49189, \\
-.44388 \\
\end{array}$ & $\begin{array}{r}- \\
3.675\end{array}$ & 81 \\
\hline $\begin{array}{l}\text { Training } \\
\text { hours/week }\end{array}$ & 13.2647 & 2.82101 & 34 & 12.4082 & 2.66081 & 49 & $\begin{array}{l}-.35463, \\
2.06771 \\
\end{array}$ & 1.407 & 81 \\
\hline
\end{tabular}




\begin{tabular}{|l|r|r|r|r|r|r|r|r|r|r|}
\hline $\begin{array}{l}\text { Training } \\
\text { frequency/week }\end{array}$ & 8.2941 & 2.22288 & 34 & 8.8776 & 2.08799 & 49 & $\begin{array}{r}-1.53558, \\
.36871\end{array}$ & $\begin{array}{r}- \\
1.219\end{array}$ & 81 \\
\hline $\begin{array}{l}\text { Number of } \\
\text { competition }\end{array}$ & 4.4118 & 1.35104 & 34 & 4.0816 & 1.33599 & 49 & $\begin{array}{r}-.26592, \\
.92618\end{array}$ & 1.102 & 81 \\
\hline Rest days/week & 1.2941 & .46250 & 34 & 1.4694 & .50423 & 49 & $\begin{array}{r}-.39184, \\
.04130\end{array}$ & -61.610 & 81 \\
\hline Actual Mileage & 3866.6471 & 1407.75882 & 34 & 3276.36 & 1191.959 & 49 & $\begin{array}{r}19.93179, \\
1160.627\end{array}$ & 2.059 & 81 \\
\hline $\begin{array}{l}\text { Warm up } \\
\text { length }\end{array}$ & 22.9706 & 6.40305 & 34 & 23.7143 & 6.34100 & 49 & $\begin{array}{r}-3.57103, \\
2.08364\end{array}$ & -.523 & 81 \\
\hline $\begin{array}{l}\text { Cool down } \\
\text { length }\end{array}$ & 15.0000 & 6.19873 & 34 & 13.7551 & 7.80099 & 49 & $\begin{array}{r}-1.94886, \\
4.43866\end{array}$ & .776 & 81 \\
\hline Exposure hours & 701.8529 & 144.82469 & 34 & 631.020 & 163.9750 & 49 & $\begin{array}{r}1.34945, \\
140.3156\end{array}$ & -.523 & 81 \\
\hline
\end{tabular}

( Note. ${ }^{*} p<.05, * * p<.01$

Results of the two-independent samples t-test for female athletes overuse injury injured and uninjured athletes shows that the mean actual mileage in the year differs between injured $(\mathrm{M}=3866.65 \mathrm{SD}=1407.76, \mathrm{n}=34)$ and uninjured $(M=3276.36, S D=1191.96, n=49)$ at the .00 level of significance $(t=2.06, d f=81, p<.01,95 \%$ CI for mean difference -19.93 to 1160.63 ). On average injured athletes tend to higher mileage than uninjured. Results of the twoindependent samples t-test for female athletes overuse injury injured and uninjured athletes also shows that the mean exposure hours in the year differs between injured $(\mathrm{M}=701.85 \mathrm{SD}=144.82, \mathrm{n}=34)$ and uninjured $(\mathrm{M}=631$, $\mathrm{SD}=163.97, \mathrm{n}=49)$ at the .046 level of significance $(\mathrm{t}=-.523, \underline{\mathrm{df}}=81, \underline{\mathrm{p}}<.01,95 \% \mathrm{CI}$ for mean difference 1.35 to 140.32). On average injured athletes tend to have higher exposure hours than uninjured. Earlier studies have implicated training volume, i.e. volume of running or higher weekly mileage, as a risk factor for injuries (Lysholm \& Wiklander 1987, Marti et al. 1988, Wen 2007, Tenforde et al. 2011). In contrast, Hreljac et al. (2000) found no differences in distance run weekly between those who had never sustained an overuse lower limb injury attributed to running and those that had sustained at least one such overuse injury. The intensity of training was found to be significantly related to injury in a cohort study of 1680 runners (Walter et al., 1989). Evidence was produced to indicate that those running at least once a week over a distance of $8 \mathrm{~km}$ or more and those running all year round, had a higher risk of injury.

Results of the two-independent samples t-test for male athletes overuse injury injured and uninjured athletes shows that the mean actual mileage in the year differs between injured $(\mathrm{M}=3866.65 \mathrm{SD}=1407.76, \mathrm{n}=34)$ and uninjured $(\mathrm{M}=3276.36, \mathrm{SD}=1191.96, \mathrm{n}=49)$ at the .00 level of significance $(\mathrm{t}=2.06, \underline{\mathrm{df}}=81, \underline{\mathrm{p}}<.01,95 \% \mathrm{CI}$ for mean difference -19.93 to 1160.63). On average injured athletes tend to have higher actual mileage than uninjured. Supporting this finding are the results of a study of 451 runners involved in the 10,000 meter National Championships in New York (Jacobs \& Berson, 1986). Based on the information the runners gave in a self-report questionnaire there was a significantly greater proportion of injured runners than non-injured runners who ran more than 30 miles per week (48\% vs 67\%, p<0.001). Van Mechelen et al. (1996) found in their study of the general population that high exposure time was a risk factor for overall injury.

Results of the two-independent samples t-test for male athletes overuse injury injured and uninjured athletes shows that the mean age in the year differs between injured $(\mathrm{M}=18.23 \mathrm{SD}=2.12, \mathrm{n}=53)$ and uninjured $(\mathrm{M}=18.15$, $\mathrm{SD}=1.96, \mathrm{n}=68)$ at the .046 level of significance $(\underline{\mathrm{t}}=.776, \underline{\mathrm{df}}=119, \underline{\mathrm{p}}<.01,95 \% \mathrm{CI}$ for mean difference -.66 to $.82)$.

Table 2:-Results of t-tests and Descriptive Statistics all Overuse injured and Uninjured Male Athletes

\begin{tabular}{|c|c|c|c|c|c|c|c|c|c|}
\hline \multirow[t]{3}{*}{ Outcome } & \multicolumn{6}{|c|}{ Injury occurrence } & \multirow{3}{*}{$\begin{array}{l}\text { 95\% CI for } \\
\text { Mean } \\
\text { Difference }\end{array}$} & & \\
\hline & \multicolumn{3}{|c|}{ Injured/YES } & \multicolumn{3}{|c|}{ Uninjured/No } & & & \\
\hline & $\mathrm{M}$ & SD & $\mathrm{n}$ & $\mathrm{M}$ & SD & $\mathrm{n}$ & & $\mathrm{T}$ & $\mathrm{df}$ \\
\hline Age & 18.2264 & 2.11807 & 53 & 18.1471 & 1.95673 & 68 & $\begin{array}{r}-.65673, \\
.81544\end{array}$ & .776 & 119 \\
\hline Height & 1.7389 & .06050 & 53 & 1.7429 & .06101 & 68 & $\begin{array}{r}-.02613, \\
.01798\end{array}$ & 2.028 & 119 \\
\hline
\end{tabular}




\begin{tabular}{|l|c|c|c|c|c|c|c|r|r|c|}
\hline BmI & 19.2342 & 1.22075 & 53 & 19.5550 & 1.47739 & 68 & $\begin{array}{r}-.81833, \\
.17663\end{array}$ & 1.277 & 119 \\
\hline Weight & 58.1887 & 5.25890 & 53 & 59.4559 & 5.89316 & 68 & $\begin{array}{r}-3.30798, \\
.77357\end{array}$ & 1.230 & 119 \\
\hline Training age & 2.5849 & 1.13398 & 53 & 3.5588 & 1.45973 & 68 & $\begin{array}{r}-1.45547, \\
-.49237\end{array}$ & - & 119 \\
& 14.4151 & 2.69924 & 53 & 13.3382 & 2.90964 & 68 & $\begin{array}{r}.05385, \\
2.09987\end{array}$ & 2.084 & 119 \\
\hline $\begin{array}{l}\text { Training } \\
\text { hours/week }\end{array}$ & 8.9434 & 1.90561 & 53 & 8.7500 & 2.30752 & 68 & $\begin{array}{r}-.58346, \\
.97026\end{array}$ & .493 & 119 \\
\hline $\begin{array}{l}\text { Training } \\
\text { frequency/week }\end{array}$ & 4.5472 & 1.42189 & 53 & 3.5882 & 1.34092 & 68 & $\begin{array}{r}.45938, \\
1.45849\end{array}$ & 3.801. & 119 \\
\hline $\begin{array}{l}\text { Number of } \\
\text { competition }\end{array}$ & 1.0943 & .35432 & 53 & 1.4853 & .53232 & 68 & $\begin{array}{r}-.55895,- \\
.22296\end{array}$ & 4.608 & 119 \\
\hline \begin{tabular}{l} 
Rest days/week \\
\hline \begin{tabular}{l} 
Actual Mileage \\
\hline
\end{tabular}
\end{tabular} & 4761.132 & 2180.05746 & 53 & 4081.52 & 1365.21 & 68 & $\begin{array}{r}38.10767, \\
1321.097\end{array}$ & 2.098 & 119 \\
\hline Warm up length & 22.8113 & 6.21430 & 53 & 23.3676 & 6.45745 & 68 & $\begin{array}{r}-2.86106, \\
1.74841\end{array}$ & -.478 & 119 \\
\hline $\begin{array}{l}\text { Cool down } \\
\text { length }\end{array}$ & 13.7925 & 7.44301 & 53 & 14.8235 & 7.49117 & 68 & $\begin{array}{r}-3.74138, \\
1.67922\end{array}$ & -.753 & 119 \\
\hline \begin{tabular}{l} 
Exposure hours \\
\hline
\end{tabular} & 742.7925 & 144.60734 & 53 & 672.308 & 152.323 & 68 & $\begin{array}{r}16.42366, \\
124.5436\end{array}$ & 2.582 & 119 \\
\hline
\end{tabular}

( Note. ${ }^{*} p<.05, * * p<.01$

On average injured athletes tend to have higher age than uninjured. The role of age as a risk factor for injuries is controversial. Some studies of running or cross-country skiing have shown that injury risk is independent of age (Lysholm \& Wiklander 1987, Marti et al. 1988, Tenforde et al. 2011). Sandelin et al. (1980) found male skiers under 30 years to have more injuries than older skiers, and Marti et al. (1988) concluded that with increasing age the incidence of running injury decreased.

Results of the two-independent samples t-test for male long distance athletes overuse injury injured and uninjured athletes shows that the mean training age in the year differs between injured $(\mathrm{M}=2.58 \mathrm{SD}=1.13, \mathrm{n}=53)$ and uninjured $(\mathrm{M}=3.56, \mathrm{SD}=1.46, \mathrm{n}=68)$ at the .00 level of significance $(\underline{\mathrm{t}}=-4.005, \underline{\mathrm{df}}=119, \underline{\mathrm{p}}<.01,95 \% \mathrm{CI}$ for mean difference -1.46 to -.49). A high number of active training years was associated with tendon injuries. Our athletes with tendon injuries were older than those without such injuries. Knobloch et al. (2008) also reported that runners with more than ten years experience had an increased risk for Achilles tendinopathy. As also in our study, Marti et al. (1988) reported that overuse injuries in the Achilles tendon were more common in older than younger runners.

Results of the two-independent samples t-test for male athletes overuse injury injured and uninjured athletes shows that the mean number of competitions in the year in the year differs between injured $(\mathrm{M}=4.55, \mathrm{SD}=1.42, \mathrm{n}=53)$ and uninjured $(\mathrm{M}=3.59, \mathrm{SD}=1.34, \mathrm{n}=68)$ at the .00 level of significance $(\mathrm{t}=-4.005, \underline{\mathrm{df}}=119, \mathrm{p}<.01,95 \% \mathrm{CI}$ for mean difference .46 to 1.49 ). On average injured athletes tend to have less annual competition number than uninjured.

Results of the two-independent samples t-test for male athletes overuse injury injured and uninjured athletes shows that the mean training hours in the week differs between injured $(M=14.41, S D=2.7, n=53)$ and uninjured $(\mathrm{M}=13.34, \mathrm{SD}=2.91, \mathrm{n}=68)$ at the .039 level of significance $(\underline{\mathrm{t}}=2.08, \underline{\mathrm{df}}=119, \underline{\mathrm{p}}<.01,95 \% \mathrm{CI}$ for mean difference .05 to 2.1 ). On average injured athletes tend to have higher training hours in the week than uninjured.

Results of the two-independent samples t-test for male athletes overuse injury injured and uninjured athletes shows that the mean actual mileage in the year differs between injured $(\mathrm{M}=4761.13, \mathrm{SD}=2180.07, \mathrm{n}=53)$ and uninjured $(\mathrm{M}=4081.52, \mathrm{SD}=1365.21, \mathrm{n}=68)$ at the .038 level of significance $(\underline{\mathrm{t}}=2.1, \underline{\mathrm{df}}=119, \underline{\mathrm{p}}<.01,95 \% \mathrm{CI}$ for mean difference 38.1 to 1321.1). On average injured athletes tend to have higher actual mileage in the year than uninjured. 
Results of the two-independent samples t-test for male athletes overuse injury injured and uninjured athletes shows that the mean rest days in a week differs between injured $(\mathrm{M}=4761.13, \mathrm{SD}=2180.07, \mathrm{n}=53)$ and uninjured $(\mathrm{M}=1.09, \mathrm{SD}=.35, \mathrm{n}=68)$ at the .00 level of significance $(\mathrm{t}=-4.61, \underline{\mathrm{df}}=119, \mathrm{p}<.01,95 \% \mathrm{CI}$ for mean difference .56 to -.22). On average injured athletes tend to have less rest days in a week number than uninjured.

Results of the two-independent samples t-test for male athletes overuse injury injured and uninjured athletes shows that the mean exposure hours in the year differs between injured $(\mathrm{M}=742.79, \mathrm{SD}=144.61, \mathrm{n}=53)$ and uninjured $(\mathrm{M}=672, \mathrm{SD}=.35, \mathrm{n}=68)$ at the .01 level of significance $(\mathrm{t}=2.58, \underline{\mathrm{df}}=119, \mathrm{p}<.01,95 \% \mathrm{CI}$ for mean difference 16.42to -124.54). On average injured athletes tend to have higher exposure hours number than uninjured.

\section{Conclusions And Recommendations:-}

\subsection{Conclusions}

Based on this retrospective twelve-month study, we conclude that:

1. $39 \%$ of overuse injured athletes are females.61\% were females. No significance association has been shown between the occurrence of overuse injury and gender.

2. A significance difference has been shown between injured and uninjured athletes of mileage and exposure ours for male and females

3. Only male athletes Injured and uninjured athletes show significant difference in

1. Age

2. Training age

3. Number of competition

4. Rest or recovery days per week days

We conclude that significant training related and supportive factors differences are evident between injured and uninjured athletes.

\section{Recommendations}

1. Coaches should recognize their contribution to the health, safety and success of the athlete (Sharkey \& Gaskill, 2006). The coach occupies a critical position in the organizational structure of preventive effort. As a supervisor of the athlete in practice and competition, the coach must recognize potentially risky situations and either avoid them or develop strategies to minimize their danger (Weaver et al., 1996). This would be achieved by properly supervising the conditioning programme and planning the activities so as not to predispose the athlete to excessive fatigue or injury. In addition, coaches should inform athletes the risk of injuries as well as the modalities for prevention and first aid. Furthermore, the coach must ensure that sports running surfaces, equipment, especially protective equipments are of the highest quality, properly fitted and maintained

2. According to Tippett (1990), the team therapist's role in injury prevention includes the provision of education to the athletes and coaches about the risks, precautions, prevention, treatment and rehabilitation. Education should be provided to all club stakeholders on the strategies required to prevent injury, achieve peak performance, healthy playing careers and lifestyles. In addition, education on the safety and emergency policies and procedures, health care insurance coverage, review of medical forms, policies and procedures to ensure compliance are the duties of the team medical personnel. Moreover the club leader's responsibility encompasses the development; implementation and monitoring of comprehensive sport safety. Therefore, this study had complemented the training science and supportive factors for occurrence of overuse injury and profile. Further study regarding existing knowledge and the implementation of injury prevention strategies in Ethiopian context should be incorporate coaches' role.

\section{References:-}

1. Alonso JM, Junge A, Renstrom P, Engebretsen L, Mountjoy M, Dvorak J. (2009).Sports injuries surveillance during the (2007) IAAF World Athletics Championships. Clin J Sport Med 19 (1), 26-32

2. Arnason A, Sigurdsson SB, Gudmundsson A, Holme I, Engebretsen L, Bahr R. (2004). Risk factors for injuries in football. Am J Sports Med 32 (Suppl 1), S5-S16.

3. Bahr R, Holme I. 2003. Risk factors for sports injuries--A methodological approach. Br J Sports Med 37 (5), 384-392. 
4. Bahr R, Andersen SO, Loken S, Fossan B, Hansen T, Holme I. (2004). Low back pain among endurance athletes with and without specific back loading A cross- sectional survey of cross-country skiers, rowers, orienteerers, and nonathletic controls. Spine 29 (4), 449-454

5. Basler RS, Hunzeker CM, Garcia MA.( 2004). Athletic skin injuries: Combating pressure and friction. Phys Sportsmed 32 (5), 33-40.

6. Collado,sain,, Maffulli N. (2011). Incidence and distribution of pediatric sport-related injuries. Clin J Sport Med 16 (6), 500-513.

7. Dempsey RL, Layde PM, Laud PW, Guse CE, Hargarten SW. (2005). Incidence of sports and recreation related

8. Fuller CW, Ekstrand J, Junge A, Andersen TE, Bahr R, Dvorak J, Hägglund M, McCrory P, Meeuwisse WH. (2006). Consensus statement on injury definitions and data collection procedures in studies of football (soccer) injuries. Clin J Sport Med 16 (2), 97-106.

9. Fuller CW, Dick RW, Corlette J, Schmalz R. (2007). Comparison of the incidence, nature and cause of injuries sustained on grass and new generation artificial turf by male and female football players. Part 1: Match injuries. Br J Sports Med 41 (Suppl 1), i20-i26.

10. Giza E, Mithofer K, Farrell L, Zarins B, Gill T. (2005). Injuries in women's professional soccer. Br J Sports Med 39 (4), 212-216.

11. Hawkins RD, Fuller CW. (1998). An examination of the frequency and severity of injuries and incidents at three levels of professional football. Br J Sports Med 32 (4), 326-332.

12. Hreljac A, Marshall RN, Hume PA. (2000). Evaluation of lower extremity overuse injury potential in runners. Med Sci Sports Exerc 32 (9), 1635-1641.

13. Hreljac A. 2004 (). Impact and overuse injuries in runners. Med Sci Sports Exerc 36(5), 845-849.

14. Hägglund M, Waldén M, Ekstrand J. (2003). Exposure and injury risk in Swedish elite football: A comparison between seasons 1982 and 2001. Scand J Med Sci Sports 13 (6), 364-370.

15. Jacobs and bernson. (1990). Medical concerns of marathons. Curr Sports Med Rep 4 (3), 137-

16. Junge A, Dvorak J. (2000). Influence of definition and data collection on the incidence of injuries in football. Am J Sports Med 28 (Suppl 5), S40-S46.

17. Khan KM, Cook JL, Bonar F, Harcourt P, Astrom M. (1999). Histopathology of common tendinopathies. Update and implications for clinical management. Sports Med 27 (6), 393408

18. Knobloch K, Yoon U, Vogt PM. (2008). Acute and overuse injuries correlated to hours of training in master running athletes. Foot Ankle Int 29 (7), 671- 676.

19. Knowles SB, Marshall SW, Bowling JM, Loomis D, Millikan R, Yang J, Weaver NL, Kalsbeek W, Mueller FO.

20. Kujala U, Orava S, Parkkari J, Kaprio J, Sarna S. (2003). Sports career-related musculoskeletal injuries: Long-term health effects on former athletes. Sports Med 33 (12), 869-875.

21. Kujala UM. (2009). Evidence on the effects of exercise therapy in the treatment of chronic disease. $\mathrm{Br} \mathrm{J}$ Sports Med 43 (8), 550-555.

22. Lysholm J, Wiklander J Am J (1987) Sports Med 15:168-171 Macera CA. 1992 (). Lower extremity injuries inrunners. Advances in prediction.Sports Med 13 (1), 50-57. Malinzak RA, Colby SM, Kirkendall DT, Yu B, Garrett WE. (2001). A comparison of knee joint motion patterns between men and women in selected athletic tasks. Clin Biomech 16 (5), 438-.

23. Maquirriain J, Merello M. (2007). The athlete with muscular cramps: Clinical approach. J Am Acad Orthop Surg 15 (7), 425-431.

24. Marti B, Vader JP, Minder CE, Abelin T. (1988)(). On the epidemiology of running injuries. The1984 Bern Grand-Prix study. Am J Sports Med 16 (3),285- 294.

25. McDonald S, Bearcroft P. (2010). Compartment syndromes. Semin Musculoskelet Radi 14(2),236-244.

26. McMaster WC, Troup J. (1993). A survey of interfering shoulder pain in United States competitive swimmers. Am J Sports Med 21 (1), 67-70.

27. Murphy DF, Connolly DA, Beynnon BD. (2003). Risk factors for lower extremity injury: A review of the literature. Br J Sports Med 37 (1), 13-29.

28. Ristolainen, L., Heinonen, A., Turunen, H., Mannström, H., Waller, B.,Kettunen, J.A. and Kujala, U.M. (2009) Type of sport is related to injury profile: A study on cross- countryskiers, swimmers, longdistance runners and soccer players. A retrospective twelve-month study.

29. Scandinavian Journal of Medicine \& Science in Sports, in Slobounov S. (2008) Injuries in Athletics: Causes and consequences University Park,PA,USA p.8-12 
30. Snyder RA, Koester MC, Dunn WR. 2006. Epidemiology of stress $\quad$ fractures. Clin Sports Med 25 (1), 37-

31. Swenson DM, Yard EE, Fields SK, Comstock RD. (2009). Patterns of recurrent injuries among US high school athletes, 2005- 2008. Am J Sports $\quad$ Med37(8), 1586-1593.

32. Taimela S, Kujala UM, Österman K. (1990). Intrinsic risk factors and athletic injuries. Sports Med 9 (4),

33. Taunton JE, Ryan MB, Clement DB, McKenzie DC, Lloyd-Smith DR, Zumbo BD. (2002). A retrospective case-control analysis of 2002 running injuries. BrJSportsMed36(2),95-101.

34. Taunton JE, Ryan MB, Clement DB, McKenzie DC, Lloyd-Smith DR, Zumbo BD. (2003). A prospective study of running injuries: The Vancouver Sun Run "In Training" clinics. Br J Sports Med 37 (3), 239-

35. Tenforde AS, Sayres LC, McCurdy ML, Collado H, Sainani KL, Fredericson M. (2011). Overuse injuries in high school runners: Lifetime prevalence and prevention strategies. PM R 3 (2), 125-131.

36. Thelin N, Holmberg S, Thelin A. (2006). Knee injuries account for the sports related increased risk of kneeosteoarthritis. Scand J Med Sci Sports 16 (5), 329-333.

37. Van Gent RN, Siem D, van Middelkoop M, van Os AG, Bierma-Zeinstra SM, Koes BW. (2007). Incidence and determinants of lower extremity running injuries in long distance runners: A systematic review. BrSports Med 41(8), 469-480.

38. Van Mechelen W. (1992). Running injuries. A review of the epidemiological literature. Sports Med 14 (5), Van Mechelen W, Hlobil H, Kemper HC. (1992). Incidence, severity, aetiologyand prevention of sports injuries. A review of concepts. Sports Med 14 (2), 82-99.

39. Waldén M, Hägglund M, Ekstrand J. (2005). Injuries in Swedish elite football—a prospective study on injury definitions, risk for injury and injury pattern during (2001).Scand JMed Sci Sports 15 (2), 118-125. Waldén M, Hägglund M, Ekstrand J. (2006). High risk of new knee injury in elite footballers with previous anterior cruciate ligament injury. Br J Sports Med40(2), 158

40. Waldén M, Hägglund M, Magnusson H, Ekstrand J. (2011). Anterior cruciate ligament injury in elite football: A prospective three-cohort study. Knee Surg Sports Traumatol Arthrosc 19 (1),11-19

41. Walter SD, Hart LE. (1990). Application of epidemiological methodology to sports and exercise science research. Exerc Sport Sci Rev 18, 417-448.

42. Weldon EJ, 3rd, Richardson AB. (2001). Upper extremity overuse injuries in swimming. A discussion of swimmer's shoulder. Clin Sports Med 20 (3),423-438.

43. Wen DY, Puffer JC, Schmalzried TP. (1997). Lower extremity alignment and risk of overuse injuries in runners. Med Sci Sports Exerc 29 (10), 1291-1298.

44. Yard EE, Collins CL, Comstock RD. (2009). A comparison of high school sports injury surveillance data reporting by certified athletic trainers and coaches. J Athl Train $44 \quad$ (6), 645-652. 